\title{
Deconstructing Post-Industrial American Ethos: Decline of Civility and Agony of Artists in Bellow's Later Novels
}

\section{Ramzi B. Mohamed Marrouchi and Dr. Mohd Nazri Latiff Azmi}

Faculty of Languages \& Communication, Universiti Sultan Zainal Abidin, Gong Badak, 21300 Kuala Terengganu, Malaysia

\section{Abstract}

This paper sheds light on the way Saul Bellow's (1915-2005) intellectual protagonists deconstruct post industrial American ethos which are dominated by the hegemony of capitalism and the values of democracy. These heroes are deeply immersed in European liberal education, the 'Western Canon' to recall Harold Bloom; however, they are marginalized, alienated, degraded and eventually rejected by the masses, junk culture, the dictatorship of the commonplace, and the unqualified individual. Bellow's heroes predict that American culture will be overwhelmed by mass culture after the 1950s characterized by liberal democracy, [ultra capitalism], scientific experimentation,

Corresponding Author: Ramzi B. Mohamed Marrouchi ramzi.marrouchi@yahoo.fr

Received: 1 July 2019

Accepted: 18 July 2019

Published: 31 July 2019

Publishing services provided by Knowledge E

(c) Ramzi B. Mohamed Marrouchi and Dr. Mohd Nazri Latiff

Azmi. This article is distributed under the terms of the Creative

Commons Attribution License,

which permits unrestricted use and redistribution provided that the original author and source are credited.

Selection and Peer-review under the responsibility of the AICLL 2019 Conference Committee. and industrialization, inspite of the high rate of higher education. Deploring a Derridean method of deconstructionism and a Foucauldian epistemic design, they archeologically question the roots of American cultural backdrop, that is, the massive industrialization in the late age of capitalism. They centralize art, humanities, classical books, morality, and religion; and marginalize science, commodity, consumerism, technology, and psychiatry. They deconstruct all makers of culture industry based on analysis, systemization, standardization, and not imagination and creativity. To achieve human and noble norms, they admit a noble life away from the vulgarity and barbarism of the age to cite Zygmunt Bauman. Special focus is on Herzog (1964), Mr. Sammler's Planet (1970), Humboldt's Gift (1975) and The Dean's December (1982) for their common concern with this issue.

Keywords: Deconstructionism, capitalism, ethos, agony, decline of civility, madness

\section{Introduction}

This paper addresses the problematical relationship between the masses and the intellectuals. It sheds light on the aspects of the agony of Bellow's heroes, the decline of civility and the reasons behind the moral and cultural backdrop in modern America. Bellow's insight about this cultural crisis refers back to what Jose Ortega Y Gasset maintains in his The Revolt of the Masses (1985) that "the West live[s] under a dictatorship of the commonplace" (p. ix); “The unqualified individual, 'equal in law,' belongs to the 
sovereign mass" (p. x); "although the world remains in certain respects civilized, its inhabitants are barbarians [...] barbarism is defined by the absence of norms" (p. x). As shall be outlined in this chapter, "barbarians and barbarism" are coined with the select man and the mass man. The select intellectual leads a noble life, whereas the mass man chooses common life. The former, as Ortega informs, is: "impelled by his very nature to seek a norm higher and superior to himself, a norm whose authority he freely accepts," and who: "demands much of himself" (p. 52). The latter is attached to life and its worldly desires; he focuses only on the pursuit of material interests. This engenders what Dwight Macdonald terms "the culture of the mass or mass culture and the high culture" (p. 205), which is "at best a vulgarized reflection of High Culture and at worst a cultural nightmare" (p. 589). Bellow's heroes predict that American culture will be overwhelmed by mass culture after the 1950s inspite of the high rate of higher education, and refer this to what Ortega calls: "liberal democracy, [ultra capitalism], scientific experimentation, and industrialization" (p. 45).

This paper shows how Bellow's intellectual heroes observe modern American culture in terms of "junk culture, kingdom of frivolity," consuming and entertainment society (Bellow, 1995, pp. 326-7). These heroes question the lack of norms and nobility in this culture, and strive to deconstruct its fundamental assumptions. The more the masses play the role of "reality instructors," give advice to intellectuals, read junk magazines on sex and commercial goods, watch TV for gags, talk shows, violence, and pornographic movies, the more the intellectuals become alienated, and the more they develop a strategy of deconstruction which is based on books, wisdom and high thinking. The masses seem to be well adjusted to society, showy, and licentious. However, in reality they are lonely crowd, "inconstant, divided, vacillating, lacking the stone like certitude of archaic man, also deprived of the firm ideas of the seventeenth century, clear, hard theorems" (Bellow, 1964, p. 107). Bellow's intellectual protagonists strive to restore the change in the center and periphery in American society. They centralize art, humanities, classical books, morality, and religion; and marginalize science, commodity, consumerism, technology, and psychiatry. They deconstruct all makers of culture industry which is based on analysis, systemization, standardization, and not imagination and morality.

\section{Madness and the IIlusionment of Intellectuals}




\subsection{Herzog's suffering, anachronism and the search for the infinite}

Madness and illusion are emblematic features that best envisage the agony of Bellow's intellectuals and the decline of civility in modern American culture. As previously sketched, Bellow dubs this cultural agony to the irresolvable conflicts between mass and the elites of humanities, morality and amorality, humanism and technology, science and creativity which Anthony Giddens coins as "the culture of risk [and] the late modern age" (p. 7). This has been illustrated by lack of harmony and trust in the postmodern age, the multiplicity of roles, players, settings, the moral and ethical uncertainty, the moral duty of the elites and philosophers (Bauman, 1987, pp. 11-9). The dehumanization of intellectuals and the 'Death of God' deepen the alienation and anxiety of Bellow's heroes and crystallize the radical change that has occurred in American society. In her book The Human Condition (1991), Hannah Arendt diagnoses the issue asserting that: "Modern man, when he lost the certainty of the world to come, was thrown back upon himself and not upon this world; far from believing that the world might be potentially immortal, he was not even sure that it was real" (p. 254, p. 474). In short, Bellow advocates the agony of the artist and the decline of civility in America, and refers this back to the heroes' struggle against low culture ethics and the systemization and standardization of capitalism and democracy.

Herzog envisages the agony of the intellect and the decline of civility in American society. He is bumbler, victim and sufferer. Not any other story is chaotic as his because he narrates his story by the eyes of an emotionally distraught narrator, Herzog. He is the most erudite, and therefore is capable of producing agony by using an epistolary style that embellishes his faceted ideas. Divorce from his wife Madeleine ends up his life, and aggravates his physical and mental anxiety. His story, therefore, begins at the end of a failed marriage to his second wife. And as he searches for equilibrium and relief, he moves from city to city, from person to person and from one idea to another, a movement which Earl Rovit calls: "the myth of the eternal journey, or better, the eternal wandering" (p. 121). Engaged in aimless wandering, Rovit portrays him:

Consigned to eternal loneliness and eternal movement; he is prohibited from establishing permanent bonds between himself and anything else in the universe, nor can he cease in his wanderings for more than a moment to rest or take his pleasure. Bearing the history of the world on his stooped shoulders like some dreadful peddler's sack, serving ultimately and painfully as the world's conscience and memory, he can act in the present only as impotent witness. (p. 122) 
Herzog is "prohibited from establishing permanent bonds between himself and anything else in the universe." He admits that intellectuals in the humanities are responsible for civilization and humanism. He is impelled: "by the need to explain, to have it out, to justify, to put in perspective, to clarify, to make amends" (Bellow, 1964, p. 2), and this intensifies his agony and alienation. Herzog maintains that all his life has been ruined: "considering his entire life, he realized that he had mismanaged everything-everything. His life was, as the phrase goes, ruined" (p. 10), "in grief he does not know what to do" (p. 78). After having a brilliant start in his Ph.D. thesis on "The State of Nature in $17^{\text {th }}$ and $18^{\text {th }}$ Century English and French Political Philosophy" (pp. 19-23), he unexpectedly changes his focus and begins another research on "Romanticism and Christianity." Josephine Hendin explains Herzog's vulnerability by his intellectual failure in his attempts to restore the disorder of the world, his illusive success with his two wives, Daisy and Madeleine, and his peculiar sense of madness (p. 27). Herzog "admitted that he had been a bad husband, to his son and his daughter he was a loving but bad father. To his own parents he had been an ungrateful child. To his country, an indifferent citizen. To his brothers and his sister, affectionate but remote. With his friends, an egoist. With love, lazy. With brightness, dull. With power passive. With his own soul evasive" (pp. 11-12). He introduces himself as: "bad husband, loving bud bad father, ungrateful child, indifferent citizen, affectionate brother, egoist friend, lazy lover, dull, passive and evasive." His life with his family is passive; his participation in the world is not by means of positive contribution but by means of negative, but tireless, efforts of writing letters. His obsession with epistles reflects the type of his addressees, famous intellectuals, dead, alive politicians, philosophers including Moses Herzog himself: "Dear Moses E. Herzog, since when have you taken such an interest in social questions, in the external world? Until lately, you led a life of innocent sloth" (p. 68).

Herzog resists to reach the infinite. For him, it is more than an insane writer's compulsion; it is a holy ceremony of an intellectual and a declaration of war against faithless friends and the decline of civility. He says:

What can thoughtful people and humanists do but struggle toward suitable words [...] I've been writing letters helter-skelter in all directions [...] I go after reality with language. Perhaps l'd like to change it all into language, to force Madeleine and Gersbach to have a Conscience [...] I must be trying to keep tight the tensions without which human beings can no longer be called human. If they don't suffer, they've gotten away from me. And I've filled the world with letters to prevent their escape [...] I really believe that brotherhood is what makes a man human. (p. 272) 
Herzog has been struggling against mass society, their low culture and ethics of betrayal. He goes "after reality with language [...] to change it [...] to force Madeleine and Gersbach to have a Conscience." He does not consider them humans as they both betrayed him. They cannot suffer, and because of this they cannot go away from him. Herzog decides to fight with his words as he "filled the world with letters to prevent their escape." He makes lectures even he makes love with women; he reacts gently to all the evils that faced him either from his Madeleine and Gersbach, or from fake intellectuals or mass society. When Madeleine declares divorce with: terrifying menstrual ice of her rages, the look of the murderess" (p. 63), he felt anger:

What if he had knocked her down, clutched her hair, dragged her screaming and fighting around the room, flogged her until her buttocks bled. What if he had! He should have torn her clothes, ripped off her necklace, brought his fists down on her head. He rejected this mental violence, sighing. He was afraid he was really given in secret to this sort of brutality. (p. 10)

However, he internalizes his anger, and "rejected this mental violence [...] this sort of brutality." Out of wisdom and subliminal morality, Herzog does not react violently, but decides to leave his house. Bellow maintains that Herzog's inaction underpins an intellectual possessing dignity and a whole philosophy of Jewish ethics, which implies in itself that his agony is derived not only from the betrayal of Madeleine and Gersbach, or the amorality of the masses, but also from his personal romantic temperament characterized by anachronism and narcissism.

Anachronism and narcissism crystallize Herzog's personality and intensify his agony and the decline of civility. Herzog is a: "professorial type to be found in the humanities" (Bellow, 1995, p. 87), he is an academic to Bellow's mind whose place is only university in modern American society. Ironically, even in universities students are not interested in humanities and liberal education, but they are concerned with sex, love, race, degrees and sports. Herzog finds himself alienated in the place where he should be happy. This anachronistic feature makes it difficult for him to continue his relationships with women. After divorce from Daisy and Madeleine, he keeps the same habits of 'manipulating' women depending on the seventeenth and eighteenth Western thinkers. Women in a narcissistic society, Lasch says in The Culture of Narcissism (1991), demand two things in their associations with men: "sexual satisfaction and tenderness" (p. 203). On the contrary, Herzog gives them ideas and anxiety. He assumes he will: "never understand what women want. What do they want? They eat green salad and drink human blood" (pp. 41-2). Aunt Zelda, one of the representative narcissistic women, advises Herzog that a girl is expected to have: "nightly erotic gratification, safety, money, insurance, furs, 
jewelry, cleaning women, drapes, dresses, hats, night clubs, country clubs, automobiles, theater" from her husband (p. 40). Madeleine loves Gersbach because he is a family man, a practical man; while Herzog remains a man of ideas who talks about philosophy even in the intercourse. With Sono, he: "behaved like a philosopher who cared only about the very highest things - creative reason, how to render good for evil, and all the wisdom of old books. Because he thought and cared about belief" (p. 185). She cries before making love with him. Ramona is the only woman who can make him happy. "She is an ideal mixture of intellect, business, and pleasure: she is an acrobat in a sexual circus" (p. 189); "she got an MA in art history at Columbia; she runs a lucrative flower shop in Manhattan. But he runs away from her" (Rho, 1999, p. 33). Herzog's anachronistic personality cannot cope with narcissistic women and egoist system, a gesture that deepens his agony and assures the decline of civility and humanism in modern American society.

\subsection{Sammler and Humboldt: The anxiety of culture and the agony of the poet}

Sammler and Humboldt underpin similar experiences of agony and illusionment in their struggle to deconstruct mass society, low culture, capitalistic and narcissistic system. Sammler suffers because of the illusive and misleading intentions of the Enlightenment. He believes that its principles with regard to morality, happiness, sublime, and humanism remain in theory. In modern American culture, individualism and democracy do not fulfill the spirit of the Enlightenment. Sammler announces:

It has only been in the last two centuries that the majority of people in civilized countries have claimed the privilege of being individuals. Formerly they were slave, peasant, laborer, even artisan, but not person. It is clear that this revolution, a triumph for justice in many ways - slaves should be free, killing toil should end, the soul should have liberty - has also introduced new kinds of grief and misery. (Bellow, 1970, p. 228)

Sammler maintains that the modern age is deceived and betrayed by the theories of the Enlightenment which brings "new kinds of grief and misery." He agrees with Habermas (1987) who points out that the Enlightenment started at the right time and place, but took the wrong way in the nineteenth and twentieth century (p. 7). The emergence of individualism and democracy results in the cultural grief and backdrop, inspite of the massive economic development and prosperity, the alienation of intellectuals in mass society including Sammler, and a society becoming rougher, more brutal, 
more materialistic, more capitalistic, and less ethical. Physically, Sammler reflects the agony of the age as his look appears: "gloomy, pale, poor and yellowish" (16) in an age requiring power and good appearance as Bellow indicates in It All Adds Up (1995) "at the University of Chicago during the thirties, this was the preferred intellectual complexion" (p. 263). Sammler is helpless about his life, mentally exhausted and feels that society is degenerating:

Mr. Sammler ground his coffee in a square box, cranking counterclockwise between long knees. To commonplace actions he brought a special pedantic awkwardness. In Poland, France, England, students, young gentlemen of his time, had been unacquainted with kitchens. Now he did things that cooks and maids had once done. He did them with a certain priestly stiffness. Acknowledgment of social descent. Historical ruin. Transformation of society. (p. 7)

He sardonically mocks the vulgarized habits of modern society in America, and summons his lost aristocracy "Now he did things that cooks and maids had once done. He did them with a certain priestly stiffness. Acknowledgment of social descent. Historical ruin. Transformation of society." Elya Gruner, a medical doctor, is forced to do menial works to help Sammler and his daughter immigrate, and provide them with their daily expenses. Pushed in this industrialized society, Sammler opposes Darwin's theory of social evolution and maintains that modern American society developing into devolution, tragic fate of civilization, and as Rho (1999) indicates: "There spreads a general tendency of less seriousness and much irresponsibility, which results in and from the appearance of gangsters dominating society" (p. 65). Sammler is critically involved in the Holocaust, the incidents of the sixties in America, Israel's six-day war of 1967, and he considers them the result of fascist gangsters. Stanley Crouch (1996) describes Sammler in the introduction to the novel: "Mr. Sammler realizes that what has happened to him and to his family, and finally, to Jews under the Nazi shadow of genocide, is another form of gangster politics, a variation on gang wars justified by the counterfeit science of the Reich" (p. xx). Sammler analyzes the fate of his family, the Jews under the Nazi genocide as a form of political gangster which juxtaposes with Israel's 1967 war. He satirically says:

This war was a most minor affair. In modem experience, so very little. Nothing at all. And the people involved in it, the boys, after fighting, played soccer at A1 Arish. They cleared a space, and they kicked and butted, they leaped up, they trotted on the sand. Or in the shade of the hangars they took out 
their books and read biology or chemistry, philosophy, preparing for exams perhaps. (p. 252)

The boys and girls involved in the war do not know much about what is happening around them. Amidst war, they play soccer, fight, trot on the sand, read their books, and prepare for their exams. Bellow suggests that these gangsters deceive the world with peace and declare war on other peoples' territories. Sammler admits that gangsters are everywhere in the modern age. They dominate the scene: "In Russia, in China, and here (in America), very mediocre people have the power to end life altogether. These representatives - not representatives of the best but Calibans or, in the jargon, creeps will decide for us all whether we live or die. Man now plays the drama of universal death" (p. 220). He struggles to deconstruct this negative mode of life, and stand against these gangsters. The agony of civilization in America is further intensified by the metaphorical act of the black pickpocket theft and his crush by one of the crowds around Columbus Circle in New York City. "The pickpocket's importance as a symbolic actor on the stage of American mass culture reaches its peak when he exposes his penis to Sammler after recognizing that Sammler has been watching his pickpocketing performance" (Rho, 1999, p. 67), while Bellow describes the scene in details:

It was displayed to Sammler with great oval testicles, a large tan-and-purple uncircumcised thing - a tube, a snake; metallic hairs bristled at the thick base and the tip curled beyond the supporting, demonstrating hand, suggesting the fleshly mobility of an elephant's trunk, though the skin was somewhat iridescent rather than thick or rough [...] The man's expression was not directly menacing but oddly, serenely masterful. The thing was shown with mystifying certitude. Lordliness. (pp. 49-50)

Sammler reminds that sexual madness has been overwhelming Western society and America in specific, that "there was a conspiracy against the sacredness of life, [that] humankind, crazy for symbols, has been trying to utter what it does not know itself" (pp. 21, 23). The pickpocket is not a human being, but an animal. He is, Ethan Goffman (1997) insists, "a crystalized representation of Western civilization' besiegement" (p. 718). The Negro's brutality, the thief, and the Jewish gaze, Sammler, metaphorically overtone the wrong path the Enlightenment takes and the deconstructive and critical position Bellow keeps towards this change. Franz Fanon (1991) assuredly agrees with this as he says: "the Negro symbolizes the biological danger; the Jew, the intellectual danger" (p. 165), "the Jew is killed or sterilized. But the Negro is castrated. The penis is annihilated" (p. 163), "one is no longer aware of the Negro but only of a penis; the Negro is eclipsed. 
He is turned into a penis. He is a penis" (p. 170). Sammler, a representative of Jewish intellectuals, deconstructs this cultural nihilism in America and: "New York City in specific with "critical blindness and critical insight" as if the city were a literary text" (Rho, 1999, p. 70). Paul de Man (1993) says: "the literary texts are themselves critical but blinded, and the critical reading of the critics tries to deconstruct the blindness" in order to "make the unseen visible" (p. 141), "however negative it may sound," he adds, "deconstruction implies the possibility of rebuilding" (p. 140). Symmetrically Sammler reads New York City as a cultural text; and interestingly enough, "he represents de Man's position as well: he has one blind eye and one insightful eye. His left eye was wounded in the Holocaust and can distinguish just black and white, while his right eye is intuitive enough to pierce through the American culture that is invisible to the masses. He is the only one who catches sight of the pickpocketing in a crowded bus and who stands against it by reporting it to the police" (Rho, 1999, pp. 70-71).

Humboldt adds to the decline of civility the agony of the poet. His agony and frustration stem from a cultural atmosphere in America that disregards cultural elitists, and marginalizes them. Alexis de Tocqueville says in his Democracy in America (1988) that: "there is nothing more petty, insipid, crowded with paltry interests - in one word, antipoetic - than the daily life of an American" (p. 485). In his essay, "Henry James and the Artist in America," W. H. Auden (1948) believes that Europeans pay respect to intellectuals and writers and help them so that they don't have to worry about their worldly concerns, whereas in America they are disregarded by public unless they prove their fame and creativity. Auden declares:

It is perhaps harder for an American writer than for a European to resist the temptation to cheapen his product, to make it more salable, because he suffers from a lack of popular success in a way that the latter does not. Growing up in a society where the business ethos is dominant, it is difficult for him not to believe that art is a commodity like a motor car whose sales and profits are an accurate indication of value. Whereas a European, brought up in a culture which inherited the medieval conception of the clerk and the social value of the contemplative life, is spared this doubt and is indeed more likely to be guilty of unjustified arrogance toward those in "trade." (p. 39)

Humboldt wants to prove his creativity and originality through political fame and cash money. Like Herzog, he supports Stevenson in the elections against Eisenhower as he believes he will bring culture and humanism to Washington. However, after his failure, he reveals desperation and anger on anti-intellectual American culture. He is a poet, and yet, he cannot deny his being American. He lusts for money: 
With a million bucks [...] l'll be free to think of nothing but poetry [...] If I'm obsessed by money, as a poet shouldn't be, there's a reason for it. The reason is that we're Americans after all. What kind of American would I be if I were innocent about money, I ask you? Things have to combined as Wallace Stevens combined them [...] No, I go along with Horace Walpole. Walpole said it was natural for free men to think about money. Why? Because money is freedom, that's why. (Bellow, 1975, p. 159)

Humboldt is eager for money not because of the influence of the culture of materialism, but because of the symbolical function money acquires. He will be free to think only of poetry. He confesses to Citrine that "The reason is that we're Americans after all. What kind of American would I be if I were innocent about money, I ask you?" His dangling between his worldly desires and intellectual pursuits epitomizes the conflict between his morals and American ethos of money and capitalism. Humboldt illustrates his eager for luxurious life through the personification of the cars he drives. At first, he drives a Buick Roadmaster, "the American symbol of success," as a result of his best-selling "The Harlequin Ballads" (Ryan, 1981, p. 117). He is "the first poet in America with power brakes" (p. 20).

The other car is an Oldsmobile, "a big powerful car" which costs him "lots of dough to keep it in a garage, more than the rent in my fifth-floor walk-up" (p. 340). To his mind the best car makers are Cadillac, Lincoln and Benz, Buick and Oldsmobile next, and Chevrolet and Dodge at the lowest. "His cars are personified in relation with his function as a poet" (Rho, 1999, p. 113). He says, "opening the Phaedrus a few months ago, I just couldn't do it. I broke down. My gears are stripped. My lining is shot. It is all shattered. I didn't have the strength to bear Plato's beautiful words, and started to cry. The original, fresh self isn't there anymore" (p. 340). As Humboldt fades away, Citrine replaces him, and changes his car from Dodge to Benz; he calls it an "elite machine, and identifies himself as elite who leads the American culture" (p. 35). His car represents money and culture, and "an attack on it was like an attack on myself, [on the high culture, the elite]" (p. 36), Citrine says. Cantabile, like the pickpocket thief in Mr. Sammler's Planet (1972), a gangster belongs to the underground culture, severely breaks Citrine's Benz and challenges his high culture. "After the loss of the Benz, Citrine begins to decline as Humboldt did, while Cantabile and Citrine's businessman brother Julius are thriving in a Thunderbird and a Cadillac. Compared with the exasperation of the artists, the practical men are prosperous, driving expensive cars" (Rho, 1999, p. 113). In La Salle Street Citrine finds: "the Jaguars and Lincolns and Rolls-Royces of stockbrokers and corporation lawyers - of the deeper thieves and the loftier politicians and the spiritual 
elite of American business, the eagles in the heights far above the daily, hourly, and momentary destinies of men" (p. 259). Humboldt and Citrine want to show that they are up to date with modern America, but they also struggle to deconstruct a "culture where the American Dollar takes the place of the sublime, spiritual ceremony" (p. 115). After Humboldt's hospitalization and tragic death, Bellow tells that: "at the morgue there were no readers of modem poetry. The name Von Humboldt Fleisher meant nothing. So he lay there, another derelict" (p. 16). Citrine waits for his role to repeat Humboldt's tragic fate, in the meantime he mourns, regrets, feels the deep agony and loss of Humboldt: "The agony is too deep, the disorder too big for art enterprises. It's become clearer and clearer to me in Humboldt's heartbreak and madness. He performed all the stormy steps of that routine. That performance was conclusive. That - it's perfectly plain, now can't be continued" (p. 477).

\subsection{Henderson and Corde: Ontological dilemma and falsity of utopian communism}

Henderson goes through a spiritual quest to envisage human ontological dilemma in modern American society. When asked by an interviewer which of his characters was most like himself, Bellow replied without hesitation, "Henderson- the absurd seeker of high qualities," he further explains: "what Henderson is really seeking is a remedy to the anxiety over death[...]l meant him to say that human life is intolerable if we must endure endless doubt" (Steers, 1964, p. 38). Eugene Henderson, millionaire, American, pig-farmer, a lover, husband, father, son, alcoholic, would-be musician, madman, a highly educated man, a modern exemplar of American society, receives a call to adventure. Inside him the words "I want, I want, I want" relentlessly repeat themselves; and he, like Tommy Wilhelm in Seize the Day (1956), is drawn to his "heart's ultimate need." When a heart insists on its destiny, the agony is great; so too the danger. He cannot cope with the ethics of modern American society, and for this reason he decides to bring change, to deconstruct the existing values of his society. His mythical hero-journey is a quest for the means of the regeneration of a society as a whole. He says:

Oh, shame, shame! How can we? Why do we allow ourselves? What are we doing? The last little room of dirt is waiting. With-out windows. So for God's sake make a move, Henderson, put forth effort. You, too, will die of this pestilence. Death will annihilate you and nothing will remain, and there will be nothing left but junk. Because nothing will have been and so nothing 
will be left. While something still is-now! For the sake of all, get out. (Bellow, 1959, p. 40)

The ontological dilemma stems from his rhetorical questioning to the concept of death, "You, too, will die of this pestilence [...] Death will annihilate you and nothing will remain." Henderson maintains that there is a need for changing values and encountering death, "So for God's sake make a move, Henderson, put forth effort." He rejects death as a finitude and summons the resurrection of the soul, the rebirth of the spirit and the immortality of the soul. Through his guide in Africa, Romilayu, Henderson epitomizes the desire of his generation to redeem anxiety over death, the present over the future: "Millions of Americans have gone forth since the war to redeem the present and discover the future [...] it's the destiny of my generation of Americans to go out in the world and try to find the wisdom of life" (pp. 276-277). Henderson and American society, Bellow informs, refuse the death of the soul, and maintain that this is the wisdom of life. Joseph Campbell in his The Hero with a Thousand Faces (1949) writes that the hero-journey is a quest for the regeneration of the whole society:

The hero and his ultimate god, the seeker and the found, are understood as the outside and inside of a single, self-mirrored mystery, which is identical with the mystery of the manifest world. The great deed of the supreme hero is to come to the knowledge of this unity in multi-plicity and then to make it known. (p. 40)

Henderson deconstructs the concept of death as shared by common people, unifies the mystery of the inside and the outside, the self and the world; he ventures to regions of supernatural wonder to bring some moral values to his society, a society which is dominated by materialism, business and standardization. He separates from the world, penetrates to a source of power, and makes a life-enhancing return. The secret he learns is the renewal of life. He returns to tell that death is only part of a cycle: "The hero has died as a modern man; but as eternal man-perfected, unspecific, universal man-he has been reborn" (Bellow, 1959, p. 20). Henderson pictures resurrection, rebirth, being and becoming by referring to the symbolical function of the orphaned child twice. The first is in the case of his daughter. While the second is when he leaves Africa, wilderness, to New York, civilization. When Henderson's daughter, Ricey, returned to the school, bringing along with her an abandoned black infant she had found in a shoe box on the back seat of an old Buick, the headmistress called the Hendersons to inform them of the situation. Reluctantly, Henderson visited the school-in a drunken conditionand was told that Ricey would have to leave since the school had: "the psychological 
welfare of the other girls to consider" (p. 37). The protagonist challenged her decision with the contention that: "Those kids can learn noble feelings from my Ricey" who, he claimed, "is one of those rapturous girls." The headmistress would be dissuaded not from her decision, however, especially when Henderson, in trying to convince her that the baby could not possibly be his daughter's natural child, blurted out that, "The girl is a virgin. She is fifty million times more pure than you or I" (pp. 37-39). On the plane in Newfoundland over the "pure white lining of the gray Arctic silence" (p. 341), Henderson's story ends up (or begins) with the orphaned child in his arms. He has always been aware of the importance of children for their symbolical function of new beginnings. By the end, Henderson leaps with joy at the triumph of life over death recollecting king Dahfu's words: "Debris of failure fills the tomb and grave, yet a vital current is still flowing. There is an evolution. We must think of it" (p. 237). Henderson admits that a childlike joy is needed for a new beginning, that to stand against the chaos of his society and his ontological dilemma, he must realize that he and the world are one, that the voice that said "I want" should have been saying, "she wants, he wants, they want" (p. 286).

Dean Albert Corde awakens the attention to the falsity and the utopian ideology of communism. He advocates thereby the end of deep political conflict in the West, and the end of illusive attempts to reconstruct society. Bellow reveals the reality of the left, and deconstructs its fundamental ethics both historically and fictionally. When Bellow visited Romania in 1979, he predicted the collapse of the communist regime, and his prediction came true three years later. And when Dean Albert Corde visits Romania to see his hospitalized mother-in-law, Valeria, this supplies him with the opportunity to compare two different ideologies: communism and democratic capitalism. Corde informs about the dictators of Bucharest: the colonel and his secret police called securitate as much as those of Chicago, masses, which shall be addressed in details later. The colonel is a symbol of corruption and dictatorship; he is a symbolic instrument of the communist party; he controls the hospital where Valeria is taken for intensive care. Valeria was the founder of this hospital, and served as the Minister of Health before Ceausescu's regime, and yet she is disregarded. The hospital looks like an old prison with its yellow and pale paints with monsters ruling its inhabitants. The colonel restricts Corde's and Minna's visit to Valeria not because Valeria is medically prohibited from contact with outsiders, but because the colonel wants to show his authority on these two famous Americans. Corde remarks that "nothing was big except the colonel's authority" (Bellow, 1982, p. 3). 
Bureaucratic dictatorship occurs in Romania, results in the emergence of a new kind of aristocracy, and not that of intellect or ability, but an aristocracy of right-thinkers and conformists. The colonel is an example of this social reformation. He is not a genuine Marxist but one of the "New Class [who lives like] Texas Millionaires" (p. 131). He takes the place of old Romanian aristocrats like Valeria and Dr. Raresh, not their ideal socialism, philosophy, morality and virtue but their social benefits. The colonel's authority is challenged when the two Americans, Corde and Minna, visit Valeria without his permission. They have not been disillusioned yet with the ideology of Communism at that time. "The hospital is a place of life and death to them, not a space for ideology and its argument. They make the same kind of mistake when they contact an American ambassador, urging him to defeat the Colonel's sovereignty. The result is a worsening of the situation. They will be allowed to visit Valeria only one more time before she dies" (p. 149). This reveals the culture of Communism which is characterized by totalitarianism and authoritarianism existing in one dimensional man and society. In Darkness at Noon (1968), Arthur Koestler says that:

It is a basic rule of Communist discipline that, once the Party has decided to adopt a certain line regarding a given problem, all criticism of that decision becomes deviationist sabotage. In theory, discussion is permissible prior to the decision. But as all decisions are imposed from above, out of the blue, without consulting any representative body of the rank and file, the latter is deprived of any influence on policy and even of the chance of expressing an opinion on it. (p. 43)

The colonel is a symbolical aspect of this one dimensional man. He is a man of power; he is a decision taker, the builder, the teacher. In his Romania in Turmoil (1993), Martin Rady describes him as "the Architect; the Builder; the Creed-shaper; a Danube of Thought; an Epoch; Father; Genius of the Carpathians; our secular God; wise Helmsman; sweet Kissing of the earth; Lawgiver; tallest Mast; Nimbus of victory; Oak tree; Prince Charming; the embodiment of Romania [...] Son of the sun; Titan; and Visionary" (pp. 49-50). Valeria, Dr. Raresh and Dr. Voynich represent the intellectuals of high culture in Romania, while the culture under the regime of Ceausescu is low culture. Dr. Raresh introduces brain surgery to Romania and serves as a Minister of Health. He is an idealist and utopian communist; he welcomes Russian soldiers, but they betray him when they steal his watch and Mercedes. "He lacks the pragmatism to cope with the new political realities of the socialist state" (Aderman, 1984, p. 44). Valeria possesses the same traits as her husband. She is the founder of the hospital where she is hospitalized now; she is a major feminine aristocratic figure in modern Romania. They are disregarded and 
destined to be ostracized by communists. They have a dream of equal social system, but they are disillusioned. Dr. Voynich is another intellectual who witnesses the broken dream of communism. Being a political critic of Ceausescu's regime, he is sentenced to more than ten years, set free, and used by the system in terms of advertisement to play the role of the happiest man. Dr. Voynich becomes another Spangler, journalist and spokesman of Ceausescu in Washington; and Vlada, Minna's friend and scientist at Chicago University, reminds Corde that it is nothing for them to be a Dean, but a famous journalist with connections with the Ambassador. Corde criticizes the communist regime and predicts its failure as it increases the sufferings of people, and Bellow behind this criticizes the double-faced ideology of American contradictory capitalism and democracy as it provides the means to this regime to control its people.

Corde informs about bribery as another aspect of corruption in communist Romania. Minna announces that: "whatever we have to do, cigarettes will make it easier," and Corde agrees, "A pack or two of king-sized Kents saved dreary hours of waiting" (Bellow, 1982, pp. 169, 170). Martin Rady (1993) confirms this: "The usual barter commodity was a packet of Kent cigarettes, which was equivalent to a dollar or 15 litres of petrol" (p. 65). When Corde deals with documents for Valeria's funeral, he observes: "No waiting. He (Traian) went to the head of the line. He presented himself at the desk boldly, making essential signals, and putting down the cigarettes" (Bellow, 1982, p. 170). The power of cigarettes makes the impossible possible, and Rho (1999) confirms this as he says: "The bribes are accepted without pretension or compunction. They are spread wide over the communist society. Both the givers and the receivers consider them naturally" (p. 155).

Another threat that deepens Corde's illusions about communist Romania is the emergence of a new bourgeois mentality. Gherea is an expert at brain surgery; he is not a man of culture and philosophy, nor is he a man of idealism. He says, "You don't give me five hundred thousand lei, I don't remove your brain tumor" (Bellow, 1982, p. 23). He wouldn't operate on the dictator's son without money. Besides making money, he spends all the rest of his time on sex. He is no man of "pictures, music" (p. 23). He is an avatar of money and sex. He is a knowledge machine whom even the dictator has no means to control. The concierge loanna is less threatening than Gherea, yet she plays multiple and contradictory roles: "Whenever Valeria went abroad, loanna's name was high on her shopping list [she] big on emotion, loyal to the family, fully informed, very potent, dangerous to neglect [she] protected, loved and blackmailed the old sisters. How to interpret this?" (p. 72). Corde's illusions about Romania come true when Ceausescu and his wife Elena were executed by rebellious mob. Communism which had lasted from 1965 to 1989 fell apart. Valeria passed away a decade before 
Ceausescu, and Bellow's predictions about Romanian communism are right at least in The Dean's December.

\subsection{Madness, illusion and deconstruction}

Bellow advocates that madness and the illusion of his heroes can only tell stories of marginalized and disregarded intellectuals, and predict histories of nations and ideas. Madness as wisdom and illusion as over consciousness trigger off deconstruction. Madness as wisdom and over consciousness reveals the disillusionment of Bellow's protagonists and their struggle to deconstruct the ethics of crowd and low culture. Echoing Althusser's definition of madness in his The Future Lasts Long Time (1993), Bellow sets the links between madness, illusion, amorality and deconstruction. Julia Eichelberger (1999) elaborates on this fact by admitting that Bellow's typical beginnings in his novels are scrupulously associated with mad intellectuals. She offers that Herzog, Henderson, Sammler, Benn Crater, Humboldt and Mr. Corde, respectively professor, philosopher, historian, poet and Dean, begin their stories with an already sense of madness and moral solitude. More strikingly, she believes that the protagonists' sense of their own stories is contaminated from the outset by their nonsense of stories in general (pp. 22-7). Stories are lies we tell ourselves about our lives. Herzog, Henderson, Sammler, Humboldt, Corde and Ravelstein have ceaselessly strived to escape the fate of writing down their own stories: "If I had died I would naturally have been released from the promise I had made years ago to write a short description of Ravelstein and to give an account of his life" (Bellow, 2000, p. 230), again "I have always a weakness for footnotes. For me a clever or a wicked footnote has redeemed many a text. And I see that I am now using a long footnote to open a serious subject" (p. 2). Asa Leventhal in The Victim (1947) sketches his madness by overemphasizing his guilt for matters for which he is not responsible. Joseph in Dangling Man (1944) assumes that he is "[...] alienated, distrustful, find in [his] purpose not an open world, but a closed, hopeless jail," he continues, "My perspectives end in the walls. Nothing of the future comes to me" (p. 92). Like Althusser, Joseph acquaints madness with his being enrolled in military services and his sacrifice for his Jewish ideals. Death to Joseph becomes a sort of noble madness that provides him with a high purpose and a sense in life to think with Carl Jaspers. Billy Rose largely advocates that his madness stems from his inability to: "forget about remembering" (Bellow, 1989, p. 2). The reader, in light of this, has been endlessly reminded of a rhythm of madness that keeps reverberating throughout Bellow's later novels. 
In his essay "Herzog, or, Bellow in Trouble" (1975), Richard Poirier redefines Bellow's madness in tune with the wasteland and absurd literature. Mental trouble, to his mind, becomes a key concept that allows having free access to the subject's psyche (p. 7). Poirier demystifies that Bellow's theory of madness is to be investigated in relationship with the bankruptcy of contemporary American culture. Located within the Jewish intellectual context, Bellow, Poirier argues, is far more alienated than Mailer, Malamud, Roth, and the others as he strived to relate his writings to amorality, madness, boredom, weariness, alienation, exile, risk, disorder and uncertainty (pp. 22-7). In his preface to The Last Analysis (1965), Bellow informs that his: "real subject is the mind's comical struggle for survival in an environment of Ideas-its fascination with metaphors, and the peculiarly literal and solemn manner in which Americans dedicate themselves to programs, fancies, or brainstorms" (p. 18). This, according to Irving Malin, suggests a sense of mental illness since madness surprisingly stems from intellectualism and sanity. The play, he admits, introduces a sharp attack on all sorts of theoreticians and becomes an epitome of the literature of absurdity. The playwright turns to be an "amateur philosopher" (pp. 115-121), his clownish subject, Bummy, performs a mental comedy; in a typically Shakespearian manner, a play within the play, he suffers from an odd disorder that he calls "Humanitis" "Suddenly being human is too much for me" (p. 21). He faints, staggers with emotion. He alternately loves and hates the others (and his own reflection in them). He becomes serious: "I don't have the strength to bear my feelings" (p. 33). He leaves the stage; he "dies" (p. 34).

In the same play, Bummy addresses the closed-circuit audience of analysts and agents: "Sixty one years ago I was literally nothing. I was merely possible. Then I was conceived, and became inevitable. When I die I, I shall be impossible. Meanwhile between two voids, past and future, I exist" (p. 7). These words are grand, sublime; they denote Bellow's "dangling men" existing between two voids, Herzog procrastinating the act of killing his wife, Augie's ceaseless Crusoe's journeys in the cities of America and Wilhelm's mental paralysis. Bummy, akin to other Bellovian subjects, is suggesting that the sense of life stems only from void and madness. Adopting a Foucauldian archeological strategy and a Derridean deconstructive method, Bummy creates the meaning through the past and the present, self and non self, the marginal and the essential, madness and reason. It is, as he says, "my personality, my mind! My mind has a will of its own" (p. 12). Summoning death, Bellow's mental comedy is linked to death and madness: "Organisms without death have no true identity" (р. 12). Hattie in Bellow's short story "Leaving the Yellow House" aggravates the scrupulous link between death, madness and intellectualism: "To lie awake and think such thoughts was the worst thing 
in the world. Better death than insomnia. Hattie not only loved sleep, she believed in it" (Bellow, 1965, p. 12), she continues to think: "I used to wish for death more than I do now. Because I did not have anything at all [...] God! What shall I do? I have taken life. I have lied. I have born false witness. I have stalled. And now what shall I do? Nobody will help me" (pp. 33, 36). By laughing at their small and unnatural roles, one discovers that there is no last analysis by the end of the play and no final truth by the end of Hattie's story. Henderson visualizes his intellectual madness as a way of sacrifice, a movement towards death and resurrection: "[...] your majesty move over and l'll die beside you. Or else be me and live; I never knew what to do with life anyway, and I'll die instead" (p. 262). Tommy Wilhelm in Seize the Day (1956) overtones his madness by reflecting on his never-ending conflicts and misunderstanding with his father and society around him. Uncle Benn and Humboldt dramatize madness, in a typically Althusserian gesture, by examining the evolution of knowledge throughout history. In short, one can safely venture to say that Bellow's madness has two fundamental aspects: one is related to the subjects' deconstruction, while the other has to do with the historical, social and political context that frames the novelist's thought.

Ihab Hassan analyzes Bellow's 'theory' of madness in relationship with the major characteristics of modernity and postmodernity. He emphatically enumerates the common traits between madness and postmodernity as follows: Dadaism, antiform (disjunctive, open), play, chance, anarchy, exhaustion/silence, process, performance, recreation, deconstruction, subversion, antithesis, absence, dispersal, text/intertexts, combination, surface, misreading, difference, difference, trace, irony, immanence (Hassan, 161, pp. 71-98). Even though one ventures to add some other features, the list would only be more unsettled and incomplete than ever. In tune with this, Hassan acknowledges that what we cannot speak about, we consign to madness, the assault on reason, absurdity, disorder and silence. Silence, to his sense: "implies alienation from reason, society and history [...] requires the periodic subversion of forms [...] creates anti-languages [...] fills the extreme states of the mind-void, madness, outrage [...] and presupposes apocalypse" (p. 13). Most of all these strategic features inform the quality of Bellow's madness, and Hassan's list works only to further deepen the novelist's view of madness. Humboldt, a poet and thinker, presents a faithful image to this claim: "he was a manic depressive (his own diagnosis). He owned a set of Freud's works and read psychiatric journals [...] he stressed that ruinous disorders follow us disquietly to our graves," (p. 5). Again, he interestingly admits that: "history was a nightmare during which he was trying to get a good night's rest. Insomnia made him more learned. In the small hours he read thick books-Marks and Sombart, Toynbee, Rostovtzeff, Freud, [...] Hegel, Kant, 
and Heidegger" (pp. 5-11). Humboldt is a great entertainer but tragically is going insane. Like Hassan's long list that fuses madness with postmodernity, Humboldt has his own list that includes: alienation, depression, madness, beauty, love, waste land, history, the unconscious, silence, boredom, sublime and death. Sanity becomes a moment of illusion and uncertainty; rather, it is the wisdom of disregarded intellectuals. This interestingly goes with the other heroes including Herzog, Henderson, Corde, Sammler and even Ravelstein. Bellow's subversion to the previously outlined moral ideals is in line with subverting the Enlightenment ideals stressing thereby the principles of recuperation, recycling, remotivation, erasure, revision, signature, parody, as being fundamental items that qualify the novelist's definition of subversion and deconstruction. It is perhaps this sort of subversion that lies at the root of the ambivalent position that Bellow holds in the critical circles. The issue, according to Ihab Hassan, is whether the novelist acknowledges more modern utopian ideals than postmodern principles and/or whether Bellow's strategies of subversion are of no crucial value, since postmodernity can only be seen as a masquerade which attempts to make things ever and even newer than they are. If the second thesis is right, then it intensifies the novelist's strategy to subvert the utopias of the past and live with the fictions of the future. Advocating that Bellow is an early postmodern practitioner further aggravates his theories of art, life, subversion and deconstruction. This, one sees it, endorses the assumption that one should not impose a specific method of reading onto the work of a writer who has perhaps never been aware of any theoretical input of the sort described by Hassan, Derrida, Foucault and others.

\section{Conclusion}

To embark on the agony of the artist and the decline of civility in Saul Bellow's later novels is as difficult as it is necessary. The difficulty arises from the nature of the cultural background which silently lurks behind Bellow's protagonists and their attempts to subvert the deconstructive forces of masses and low culture. Deconstructionism and Bellow's protagonists are commonly regarded as open texts, indefinable processes; projects of writing that develop only through subversion and deconstruction. While the necessity stems from the postulate that one could not gain a deep insight into the mind and the world of the novelist without deploring the plethora of the newly emerging findings of the deconstructive theory. Strikingly, in being both beyond the reach of definition and closure, they interestingly meet on one ground: the survival of the elites and intellectuals in a society which is dominated by the hegemony of capitalism and 
the values of democracy. In this way it becomes fundamental to investigate how these heroes are alienated, marginalized, degraded and rejected by the masses in modern American cultural scene, how their agony and marginalization result in the decline of civility and the end of humanism, how do these intellectuals deconstruct the ethics of masses, and find their way amidst this cultural and intellectual backdrop. Eventually, one can always ask about the role capitalism and democracy play to aggravate the agony of Bellow's heroes and the decline of moral values which the novelist refers to as high culture.

\section{References}

[1] Althusser, Louis. (1993).The Future Lasts Long Time. Trans. Richard Veasey. London: Chatto and Windus.

[2] Arendt, Hannah. (1991). The Human Condition. Chicago: Chicago University Press.

[3] Auden, W. H. "Henry James and the Artist in America." Harper's Magazine July 1948: 36-40.

[4] Bauman, Zygmunt. (1987). Legislators and Interpreters: On Modernity, Postmodernity and Intellectuals. Cambridge: Polity Press.

[5] Bellow, Saul. (1944). Dangling Man, New York: Vanguard Press,

[6] (1947). The Victim, New York: Vanguard Press.

[7] _ . (1956). Seize the Day, New York: Vanguard Press.

[8] _ . (1959). Henderson the Rain King, New York: Viking Press.

[9] _ (1964). Herzog, New York: Viking Press.

[10] _ (1965). Leaving the Yellow House. New York: Penguin.

[11] _ . (1970). Mr. Sammler’s Planet, New York: Viking Press.

[12] _ . (1975). Humboldt's Gift, New York: Viking Press.

[13] _ . (1982). The Dean's December, New York: Vanguard Press.

[14] _ (1989). The Bellarosa Connection. New York: Penguin.

[15] _ . (1995). It All Adds Up: from the Dim Past to the Uncertain Career, New York: Penguin.

[16] _ (2001). Ravelstein, New York: Penguin.

[17] _ (1965). The Last Analysis. New York: Penguin.

[18] Campbell, Joseph. (1949). The Hero with a Thousand Faces. Princeton, New Jersey: Princeton University Press. 
[19] Crouch, Stanley. (1996). "Barbarous on Either Side: The New York Blues of Mr. Sammler's Planet." Introduction. Mr. Sammler's Planet. By Saul Bellow. New York: Penguin Books.

[20] De Man, Paul. (1993). Blindness and Insight. London: Routledge.

[21] Eichelberger, Julia. (1999). Prophets of Recognition: Ideology and the Individual Novels by Ralph Ellison, Toni Morrison, Saul Bellow, and Eudora Welty. Baton Rouge: Louisiana State UP.

[22] Fanon, Frantz. (1991). Black Skin, White Masses.Trans. Charles Lam Markmann. New York: Grove Press.

[23] Giddens, Anthony. (1991). Modernity and Self-ldentity: Self and Society in the Late Modern Age. Cambridge: Polity Press.

[24] Goffman, Ethan. (1997). "Between Guilt and Affluence: The Jewish Gaze and the Black Thief in Mr. Sammler's Planet." Contemporary Literature. Indiana: IUP.

[25] Habermas, Jrgen. (1987). The Philosophical Discourse of Modernity. Trans. Frederick G. Lawrence. Massachusetts: The MIT Press Cambridge,

[26] Hassan, Ihab. (1961). Radical Innocence: The Contemporary American Novel. Princeton, New Jersey: Princeton University Press.

[27] Koestler, Arthur. (1968). Darkness at Noon. Trans. Daphne Hardy. New York: Bantam Books.

[28] Lasch, Christopher. (1991). The Culture of Narcissism: American Life in an Age of Diminishing Expectations. New York: W. W. Norton. Mayer. New York: Harper Perennial.

[29] Ortega Y Gasset, Jose. (1985). The Revolt of the Masses. Trans. Anthony Kerrigan. Ed. Kenneth Moore. Notre Dame, Indiana: University of Notre Dame Press.

[30] Rady, Martin. (1992). Romania in Turmoil. London: IB Tauris.

[31] Rho, Heongyun. (1999). Alienation of Intellectuals in Saul Bellow's Later Novels. New York: University of New York.

[32] Rovit, Earl, ed. (1975). Saul Bellow: A Collection of Critical Essays. Eaglewood Cliffs, New Jersey: Prentice-Hall.

[33] Ryan, Steven T. (1981). “The Soul's Husband: Money in Humboldt's Gift.” Money Talks: Language and Lucre in American Fiction. Ed. Roy R. Male. Norman: University of Oklahoma Press.

[34] Steers, Nina. "Successor to Faulkner?" Show. IV (Nov. 1964), 38. Aderman, Ralph M. "The Dean's Bucharest: Saul Bellow and Romania." Journal of the American Romanian Academy of Arts and Sciences 5 (1984): 41-8. 
[35] Tocqueville, Alexis de. (1988). Democracy in America. Trans. George Lawrence. Ed. J. P. 